\title{
A determination of the standards of morphometrics variables of the stomatognathic system of a fetus
}

\author{
Salaga-Nefic, Samra ${ }^{1}$; Mehmedbasic, Senad ${ }^{2}$; Kozadra, Jasmina ${ }^{3}$; Zukanovic, Amila ${ }^{3}$; Tiro, Alisa ${ }^{3}$; \\ Dzemidzic, Vildana ${ }^{3}$; Nakas, Enita ${ }^{3}$ \\ 1 Private Private Dental Practice, Switzerland \\ 2 Institute for Gynecology, Perinatology and Infertility, BiH \\ 3 University of Sarajevo, Sarajevo
}

\begin{abstract}
Introduction: Many factors affect the growth and development of the mandible. The most common one is micrognathia; this can pose and neonatal emergency. Early recognition of mandibular and other face anomalies could provide immediate care for these infants, and presence of neonatologist or other doctors in the delivery room.

The aim: Aim of this study was to develop normal ranges of the facial markers: mandibular length, jaw index and the facial angle in the fetus using $3 \mathrm{D}$ ultrasound.

Material and methods: The research was conducted as a cross-sectional study in the second trimester of pregnancy. Fetuses (female $\mathrm{n}=23$ and male $\mathrm{n}=27$ ) from singleton pregnancy between 29-37 week of gestation were examined by ultrasound. All images were acquired transabdominally, using Voluson E16. Ultrasound was performed by an experienced operator (SM) and measured the values of head circumference, abdominal circumference, biparietal diameter, femur length, body mass. For mandibular length, inferior facial angle, and the jaw index was calculated (Jaw Index =AP mandibular diameter / BPD * 100), the profile images were used (only images in the exact midsagittal plane were used). The characteristics of the fetal profiles were determined by the Schwartz and Ricketts profile analysis using soft tissue landmarks and analysis of the profile photographs.
\end{abstract}

Results: The results show that the jaw index ranged from 25.33 and 34.06 with an average of 26.00 for all examined fetuses.

Conclusion: The physiological position of the mandible is retrognathic and that the average physiological length of the mandible in the third trimester is $2.31 \mathrm{~cm}$. There is no difference in mandibular length between genders.

Salaga-Nefic S., Mehmedbasic S., Kozadra J., Zukanovic A., Tiro, A., Dzemidzic, V., Nakas E. A determination of the standards of morphometrics variables of the stomatognathic system of a fetus. South Eur J Orthod Dentofac Res. 2019;6(1):6-11.

Submitted: July 30, 2018; Revised: March 7, 2019; Published: April 30, 2019

\section{INTRODUCTION}

Many factors affect the growth and development of the mandible: genes, irregular cell migration, low growth potential, feeding habits, and other habits acquired by newborns. ${ }^{1}$ The most common anomalies are microgenia (weak mandible growth) and retrogenia (small mandible growth in the sagittal plane). ${ }^{1}$ Deviation of physiological mandibular growth and development may incapacitate the essential functions of the stomatognathic system. Fetuses with mandible anomalies are at risk of airway obstruction through retro-positioning of the tongue-base into posterior pharyngeal airway. ${ }^{2}$ Micrognathia is

Corresponding Author:

Samra Salga-Nefic

Rosenweg 2a, 3125 Toffen, Switzerland,

e-mail: samrasalaga@gmail.com frequently seen in Pierre Robin sequence, however it can be found in many genetic syndromes. ${ }^{3}$

Antenatal diagnosis of anomalies by ultrasound is widely used nowadays.

The aim of this study was to develop normal ranges of the facial marker: mandibular length, jaw index and the facial angle in the fetus using $3 \mathrm{D}$ ultrasound.

\section{MATERIAL AND METHODS}

The research was conducted as a cross-sectional study in the second trimester of pregnancy. Fetuses (female $n=23$ and male $n=27$ ) from singleton pregnancy between 29-37 week of gestation were examined by ultrasound. All images were acquired transabdominally, using ultrasound Voluson E16, GE Healthcare, Austria GmbH \& Co OG. 


\section{Parameters and measurements:}

Ultrasound was performed by an experienced operator (SM) and measured the values of head circumference, abdominal circumference, biparietal diameter, femur length, body mass. For mandibular length, inferior facial angle, and the jaw index was calculated (Jaw Index $=$ AP mandibular diameter / BPD * 100). The profile images in the exact midsagittal plane were used. The characteristics of the fetal profiles were determined by the Schwartz and Ricketts profile analysis using soft tissue landmarks and analysis of the profile photographs. The profile was analyzed using the Schwarz and Ricketts method. The positions of four soft tissue landmarks: the tip of the upper lip, lower lip, skin pogonion, and subnasale were compared to three lines: the Dreyfus line, Simon line, and the E-line. A positive value indicates that the landmark is anterior to the line and a negative value indicates that the landmark is posterior to the line. Each measurement was evaluated twice, and the mean value was used as relevant.

\section{RESULTS}

Table 1 shows measured values of fetal development parameters between the 29th and 37th gestational week.

Table 1. Distribution of fetal development parameters

\begin{tabular}{|c|c|c|c|c|c|c|c|c|c|}
\hline GW & & HC & BPd & FL & AC & BM & ML & IFA & JI \\
\hline \multirow{3}{*}{29} & Mean & 25.300 & 7.500 & 6.060 & 22.520 & 1203.000 & 1.900 & 47.500 & 25.330 \\
\hline & Standard error of Mean & & & & & & & & \\
\hline & Standard Deviation & & & & & & & & \\
\hline \multirow{3}{*}{30} & Mean & 29.277 & 8.233 & 6.137 & 27.263 & 1923.000 & 2.000 & 52.167 & 24.290 \\
\hline & Standard error of Mean & 0.617 & 0.077 & 0.119 & 0.252 & 15.100 & 0.000 & 1.424 & 0.230 \\
\hline & Standard Deviation & 1.068 & 0.133 & 0.206 & 0.437 & 26.153 & 0.000 & 2.466 & 0.398 \\
\hline \multirow{3}{*}{32} & Mean & 29.127 & 8.392 & 6.080 & 27.444 & 2035.333 & 1.994 & 56.500 & 23.978 \\
\hline & Standard error of Mean & 0.535 & 0.101 & 0.201 & 0.582 & 109.301 & 0.102 & 3.639 & 1.163 \\
\hline & Standard Deviation & 1.606 & 0.304 & 0.604 & 1.746 & 327.904 & 0.307 & 10.917 & 3.489 \\
\hline \multirow{3}{*}{33} & Mean & 29.499 & 8.563 & 6.350 & 28.609 & 2231.667 & 2.356 & 58.056 & 27.502 \\
\hline & Standard error of Mean & 0.318 & 0.153 & 0.081 & 0.458 & 111.675 & 0.146 & 3.269 & 1.939 \\
\hline & Standard Deviation & 0.953 & 0.459 & 0.244 & 1.374 & 335.025 & 0.438 & 9.806 & 5.817 \\
\hline \multirow{3}{*}{34} & Mean & 31.010 & 9.255 & 6.804 & 30.105 & 2655.625 & 2.000 & 60.938 & 21.538 \\
\hline & Standard error of Mean & 0.174 & 0.011 & 0.035 & 0.055 & 23.125 & 0.000 & 0.979 & 0.053 \\
\hline & Standard Deviation & 0.493 & 0.032 & 0.099 & 0.154 & 65.408 & 0.000 & 2.770 & 0.150 \\
\hline \multirow{3}{*}{35} & Mean & 31.528 & 9.068 & 6.925 & 31.623 & 2873.500 & 2.775 & 55.833 & 30.596 \\
\hline & Standard error of Mean & 0.052 & 0.008 & 0.017 & 0.020 & 2.513 & 0.017 & 0.691 & 0.174 \\
\hline & Standard Deviation & 0.126 & 0.019 & 0.042 & 0.050 & 6.156 & 0.042 & 1.693 & 0.427 \\
\hline \multirow{3}{*}{36} & Mean & 31.517 & 9.360 & 7.026 & 30.316 & 2777.300 & 2.305 & 41.300 & 24.619 \\
\hline & Standard error of Mean & 0.340 & 0.046 & 0.039 & 0.187 & 30.093 & 0.032 & 0.611 & 0.285 \\
\hline & Standard Deviation & 1.074 & 0.145 & 0.124 & 0.593 & 95.163 & 0.101 & 1.932 & 0.903 \\
\hline \multirow{3}{*}{37} & Mean & 32.315 & 9.263 & 7.125 & 31.910 & 3071.500 & 3.156 & 48.750 & 34.069 \\
\hline & Standard error of Mean & 0.151 & 0.063 & 0.039 & 0.477 & 86.195 & 0.026 & 0.924 & 0.160 \\
\hline & Standard Deviation & 0.302 & 0.125 & 0.079 & 0.953 & 172.390 & 0.052 & 1.848 & 0.320 \\
\hline
\end{tabular}

GW - Gestational Week, HC - Head Circumferences, BPd - Biparietal diameter, FL - Femur Length, AC - Abdominal Circumferences, BM - Body Mass, $\boldsymbol{M L}$ - Mandibular Length, IFA - Inferior Facial Angle, JI - Jaw Index 
Table 2 shows the measurements of the mandibular length correlated with the habits as follow. There is no correlation between the habits of the pregnant women, the gender of the fetus and the value of the mandibular length.

Table 2. Measurements of Mandibular Length cross-referenced with the habits of the mothers

\begin{tabular}{|c|c|c|c|c|c|c|c|c|c|}
\hline & & Count & Minimum & Maximum & Range & Mean & Median & $\begin{array}{l}\text { Standard } \\
\text { deviation }\end{array}$ & Variance \\
\hline Question & Answer & 50 & 1.6 & 3.4 & 1.8 & 2.31 & 2.23 & 0.42 & 0.18 \\
\hline \multirow{2}{*}{ Did the mother consume tobacco? } & Yes & 14 & 1.6 & 3.4 & 1.8 & 2.28 & 2.23 & 0.49 & 0.24 \\
\hline & No & 36 & 1.8 & 3.225 & 1.425 & 2.32 & 2.23 & 0.40 & 0.16 \\
\hline \multirow{2}{*}{ Did the mother consume alcohol? } & Yes & 1 & 2.5 & 2.5 & 0 & 2.50 & 2.50 & & \\
\hline & No & 49 & 1.6 & 3.4 & 1.8 & 2.30 & 2.20 & 0.42 & 0.18 \\
\hline \multirow{2}{*}{ Did the mother consume narcotics? } & Yes & 3 & 2.2 & 2.8 & 0.6 & 2.42 & 2.25 & 0.33 & 0.11 \\
\hline & No & 47 & 1.6 & 3.4 & 1.8 & 2.30 & 2.20 & 0.43 & 0.18 \\
\hline \multirow{2}{*}{ Does the mother have dental irregularity? } & Yes & 17 & 1.8 & 3.15 & 1.35 & 2.27 & 2.20 & 0.37 & 0.14 \\
\hline & No & 33 & 1.6 & 3.4 & 1.8 & 2.33 & 2.25 & 0.45 & 0.20 \\
\hline \multirow{2}{*}{ Did the mother consume supplements? } & Yes & 25 & 1.6 & 3.15 & 1.55 & 2.31 & 2.25 & 0.38 & 0.14 \\
\hline & No & 25 & 1.65 & 3.4 & 1.75 & 2.30 & 2.10 & 0.47 & 0.22 \\
\hline \multirow{2}{*}{ Did the mother consume progesterone? } & Yes & 25 & 1.6 & 3.225 & 1.625 & 2.21 & 2.10 & 0.36 & 0.13 \\
\hline & No & 25 & 1.65 & 3.4 & 1.75 & 2.41 & 2.30 & 0.46 & 0.22 \\
\hline \multirow{2}{*}{ Gender of fetus } & Female & 23 & 1.6 & 3.15 & 1.55 & 2.27 & 2.25 & 0.35 & 0.12 \\
\hline & Male & 27 & 1.65 & 3.4 & 1.75 & 2.34 & 2.20 & 0.48 & 0.23 \\
\hline
\end{tabular}

Table 3 shows the values of the inferior facial angle measured in this study compared with the habits. There is no correlation between the habits of the pregnant women, the gender of the fetus and the value of the inferior facial angle. An average value of $53.3^{\circ}$ for a lower physiological minimum was defined in this study.

Table 3. Measurements of the Inferior Facial Angle

\begin{tabular}{|c|c|c|c|c|c|c|c|c|c|}
\hline & & Count & Minimum & Maximum & Range & Mean & Median & $\begin{array}{l}\text { Standard } \\
\text { deviation }\end{array}$ & Variance \\
\hline Question & Answer & 50 & 39 & 79 & 40 & 53.31 & 54.50 & 9.27 & 85.88 \\
\hline \multirow{2}{*}{ Did the mother consume tobacco? } & Yes & 14 & 41 & 79 & 38 & 57.14 & 57.75 & 11.40 & 130.05 \\
\hline & No & 36 & 39 & 67.5 & 2805 & 51.82 & 51.00 & 7.98 & 63.76 \\
\hline \multirow{2}{*}{ Did the mother consume alcohol? } & Yes & 1 & 69 & 69 & 0 & 69.00 & 69.00 & & \\
\hline & No & 49 & 39 & 79 & 48 & 52.99 & 54.50 & 9.08 & 82.43 \\
\hline \multirow{2}{*}{ Did the mother consume narcotics? } & Yes & 3 & 41 & 59.5 & 18.5 & 51.83 & 55.00 & 9.65 & 93.08 \\
\hline & No & 47 & 39 & 79 & 40 & 53.40 & 54.50 & 9.34 & 87.28 \\
\hline \multirow{2}{*}{ Does the mother have dental irregularity? } & Yes & 17 & 39.5 & 79 & 39.5 & 54.15 & 54.50 & 10.51 & 110.37 \\
\hline & No & 33 & 39 & 74 & 35 & 52.88 & 54.50 & 8.70 & 75.75 \\
\hline \multirow{2}{*}{ Did the mother consume supplements? } & Yes & 25 & 39.5 & 79 & 39.5 & 52.92 & 54.50 & 10.52 & 110.66 \\
\hline & No & 25 & 39 & 69 & 30 & 53.70 & 54.50 & 8.02 & 64.35 \\
\hline \multirow{2}{*}{ Did the mother consume progesterone? } & Yes & 25 & 39 & 74 & 35 & 51.40 & 51.00 & 9.96 & 99.29 \\
\hline & No & 25 & 41 & 79 & 38 & 55.22 & 55.00 & 8.27 & 68.44 \\
\hline \multirow{2}{*}{ Gender of fetus } & Female & 23 & 39.5 & 79 & 39.5 & 54.24 & 54.50 & 11.35 & 128.91 \\
\hline & Male & 27 & 39 & 64.5 & 25.5 & 52.52 & 54.50 & 7.17 & 51.36 \\
\hline
\end{tabular}


The values of the jaw index obtained by the 50 fetuses were correlated with the habits and table 4 shows the results of measurements.

The results show that the jaw index ranged from 25.3 and 34.0 with an average of 26.0 for all examined fetuses. A correlation was found between the use of progesterone and the fetal jaw index (Mann-Whitney test is $186.000 ; \mathrm{p}<0,05)$. In fetuses where the pregnant woman consumed progesterone, the value of the jaw index was smaller. A correlation was also found between the use of tobacco and the value of the jaw index (Mann-Whitney test is 247.500; $\mathrm{p}<0,05)$. Fetuses whose mother did not consume tobacco had a smaller lower facial angle than in cases where the mother did consume tobacco.

Table 4. Measurements of Jaw Index

\begin{tabular}{|c|c|c|c|c|c|c|c|c|c|}
\hline & & Count & Minimum & Maximum & Range & Mean & Median & $\begin{array}{l}\text { Standard } \\
\text { deviation }\end{array}$ & Variance \\
\hline Question & Answer & 50 & 18.12 & 40.9 & 22.78 & 26.00 & 24.73 & 4.54 & 20.59 \\
\hline \multirow{2}{*}{ Did the mother consume tobacco? } & Yes & 14 & 18.12 & 40.9 & 22.78 & 26.17 & 24.84 & 5.82 & 33.82 \\
\hline & No & 36 & 21.12 & 34.155 & 13.035 & 25.93 & 24.70 & 4.03 & 16.25 \\
\hline \multirow{2}{*}{ Did the mother consume alcohol? } & Yes & 1 & 29.45 & 29.45 & 0 & 29.45 & 29.45 & & \\
\hline & No & 49 & 18.12 & 40.9 & 22.78 & 25.93 & 24.70 & 4.56 & 20.77 \\
\hline \multirow{2}{*}{ Did the mother consume narcotics? } & Yes & 3 & 23.68 & 30.83 & 7.15 & 29.96 & 26.38 & 3.61 & 13.04 \\
\hline & No & 47 & 18.12 & 40.9 & 22.78 & 25.94 & 24.70 & 4.62 & 21.30 \\
\hline \multirow{2}{*}{ Does the mother have dental irregularity? } & Yes & 17 & 21.12 & 34.42 & 13.3 & 25.70 & 24.50 & 4.05 & 16.39 \\
\hline & No & 33 & 18.12 & 40.9 & 22.78 & 26.15 & 24.92 & 4.82 & 23.26 \\
\hline \multirow{2}{*}{ Did the mother consume supplements? } & Yes & 25 & 18.12 & 34.05 & 15.93 & 25.86 & 24.70 & 4.01 & 16.08 \\
\hline & No & 25 & 21.12 & 40.9 & 19.78 & 26.14 & 24.81 & 5.09 & 25.92 \\
\hline \multirow{2}{*}{ Did the mother consume progesterone? } & Yes & 25 & 18.12 & 34.155 & 16.035 & 24.46 & 24.17 & 3.84 & 14.77 \\
\hline & No & 25 & 21.12 & 40.9 & 19.78 & 27.53 & 26.38 & 4.73 & 22.36 \\
\hline \multirow{2}{*}{ Gender of fetus } & Female & 23 & 18.12 & 34.05 & 15.93 & 25.47 & 24.81 & 3.74 & 13.95 \\
\hline & Male & 27 & 21.12 & 40.9 & 19.78 & 26.44 & 24.68 & 5.15 & 26.55 \\
\hline
\end{tabular}

Table 5 shows the values of the body mass measured in this study compared with the habits. There is no correlation between the body mass of the fetus and the habits of the pregnant woman and the gender of the fetus.

Table 5. Measurements of body mass

\begin{tabular}{|c|c|c|c|c|c|c|c|c|c|}
\hline & & Count & Minimum & Maximum & Range & Mean & Median & $\begin{array}{l}\text { Standard } \\
\text { deviation }\end{array}$ & Variance \\
\hline Question & Answer & 50 & 1203 & 3192 & 1989 & 2478.40 & 2683.00 & 458.82 & 210517.63 \\
\hline \multirow{2}{*}{ Did the mother consume tobacco? } & Yes & 14 & 1707 & 3128 & 1421 & 2397.00 & 2351.00 & 411.20 & 160085.54 \\
\hline & No & 36 & 1203 & 3192 & 1989 & 2510.06 & 2690.00 & 477.75 & 228240.40 \\
\hline \multirow{2}{*}{ Did the mother consume alcohol? } & Yes & 1 & 2131 & 2131 & 0 & 2131.00 & 2131.00 & - & - \\
\hline & No & 49 & 1203 & 3192 & 1989 & 2485.49 & 2685.00 & 460.80 & 212337.80 \\
\hline \multirow{2}{*}{ Did the mother consume narcotics? } & Yes & 3 & 2255 & 2879 & 624 & 2620.00 & 2726.00 & 325.22 & 105771.00 \\
\hline & No & 47 & 1203 & 3192 & 1989 & 2469.36 & 2681.00 & 467.18 & 218257.19 \\
\hline \multirow{2}{*}{ Does the mother have dental irregularity? } & Yes & 17 & 1704 & 3128 & 1424 & 2375.29 & 2476.00 & 450.21 & 202692.22 \\
\hline & No & 33 & 1203 & 3192 & 1989 & 2531.52 & 2685.00 & 460.93 & 212452.01 \\
\hline \multirow{2}{*}{ Did the mother consume supplements? } & Yes & 25 & 1716 & 3150 & 1434 & 2518.88 & 2695.00 & 411.14 & 169039.61 \\
\hline & No & 25 & 1203 & 3192 & 1989 & 2437.92 & 2636.00 & 507.30 & 257353.41 \\
\hline \multirow{2}{*}{ Did the mother consume progesterone? } & Yes & 25 & 1704 & 3192 & 1488 & 2530.28 & 2685.00 & 411.54 & 169366.63 \\
\hline & No & 25 & 1203 & 3128 & 1925 & 2426.52 & 2476.00 & 504.81 & 254832.84 \\
\hline \multirow{2}{*}{ Gender of fetus } & Female & 23 & 1704 & 3150 & 1446 & 2506.30 & 2685.00 & 404.34 & 163487.22 \\
\hline & Male & 27 & 1203 & 3192 & 1989 & 2454.63 & 2675.00 & 507.08 & 257133.86 \\
\hline
\end{tabular}


Analysis of the fetal profile measured the distances between soft tissue landmarks and three vertical lines. Table 6 shows the results of these measurements (all values measured in millimeters).

Table 6. The position of the four soft tissue landmarks in relation to the three vertical lines

\begin{tabular}{lccccc}
\hline & N & Mean & $\begin{array}{c}\text { Standard } \\
\text { deviation }\end{array}$ & Minimum & Maximum \\
\hline $\begin{array}{l}\text { Tip of the upper lip in } \\
\text { relation to Dreyfus line }\end{array}$ & 50 & 2.48 & 1.291 & -1.00 & 5.00 \\
\hline $\begin{array}{l}\text { Tip of the upper lip in } \\
\text { relation to the Simon line }\end{array}$ & 50 & 10.09 & 1.753 & 6.50 & 13.00 \\
\hline $\begin{array}{l}\text { Tip of the upper lip in } \\
\text { relation to the E line }\end{array}$ & 50 & 0.99 & 1.699 & -1.50 & 4.50 \\
\hline $\begin{array}{l}\text { Tip of the lower lip in } \\
\text { relation to Dreyfus line }\end{array}$ & 50 & -0.81 & 2.984 & -6.00 & 4.00 \\
\hline $\begin{array}{l}\text { Tip of the lower lip in } \\
\text { relation to the Simon line }\end{array}$ & 50 & 6.75 & 1.982 & 3.75 & 10.00 \\
\hline $\begin{array}{l}\text { Tip of the lower lip in } \\
\text { relation to the E line }\end{array}$ & 50 & 0.58 & 1.646 & -3.00 & 3.00 \\
\hline $\begin{array}{l}\text { Sn in relation to Dreyfus } \\
\text { line }\end{array}$ & 50 & 1.25 & 1.125 & -1.00 & 3.00 \\
\hline $\begin{array}{l}\text { Sn in relation to the Simon } \\
\text { line }\end{array}$ & 50 & 9.04 & 1.397 & 5.25 & 11.00 \\
\hline $\begin{array}{l}\text { Pg' in relation to Dreyfus } \\
\text { line }\end{array}$ & 50 & -5.39 & 4.056 & -11.00 & 8.00 \\
\hline $\begin{array}{l}\text { Pg' in relation to the } \\
\text { Simon line }\end{array}$ & 50 & 2.19 & 3.032 & -3.00 & 8.00 \\
\hline
\end{tabular}

\section{DISCUSSION}

Intrauterine development is an intricate phenomenon that is explored in detail by many medical fields, including gynecologists, pediatricians, and orthodontists. For orthodontists, a fetal analysis may predict some future orthodontic anomalies. We began this research with an evaluation of the standard parameters of all the fetuses. We compared the acquired measurements with referent values, in order to establish that the fetuses showed normal growth and development.

The results of measurement of fetal development parameters are in agreement with the results of similar research conducted by Loughna et al., Otto and Platt, and Roelfsema et al., indicating normal growth and development. ${ }^{4-6}$

Our measurements of the mandibular length ranged from 1.9 $\mathrm{cm}$ to $3.1 \mathrm{~cm}$, with an average of $2.3 \mathrm{~cm}$, and these results are in accordance with the results of similar studies. Roelfseme et al. defined the average value of the mandible in the 18 th gestational week as $1.3 \mathrm{~cm}$ and in the 34 th week as $2.9 \mathrm{~cm} .{ }^{6}$ Watson and Katz measured fetuses between 18 and 27 gestational weeks and concluded that the average anterior-posterior diameter of the mandible was $1,8 \mathrm{~cm}$ and $2.7 \mathrm{~cm} .^{7}$ The intrauterine growth of the mandible can be tracked using the ultrasound during the fetal life. It was Zalela et al. who established the mandibular ratio: Mandibular Ratio $=1,7759(0,01047 \mathrm{x}$ gestational week $) .{ }^{8}$ The results of measuring the length of the mandible of our research are in accordance with the results of the mentioned studies.

We compared this value to the habits of the mothers, the gender of the fetus, and any dental irregularities the parents might have and found no correlation (Table 2). Unfortunately, at present, there is no additional research about the effects of the habits of the mothers and the mandibular length.

We can confidently conclude that there is no difference in mandibular length between genders. Malas et al. examined 161 fetuses between the 9th and 40th gestational week. They found that the speed of mandibular growth was almost equal among all fetuses in the third trimester. ${ }^{9}$ According to Enlow, the speed of growth and remodeling in early childhood is also the same in both genders. The only differences between genders are in the contours of the inferior margin of the symphysis and the mandible itself in the prepubescent period. ${ }^{10,11}$

The inferior facial angle was introduced by Rotten et al.as a parameter for establishing the position of the mandible in the sagittal plane. After examining fetuses between the 18th and 28th gestational week, they established an average value of $65.5^{\circ}$. Every value lower than $49.2^{\circ}$ was defined as retrognathic. ${ }^{1}$ We measured the average value of $53.3^{\circ}$.

This research did not show a correlation between the value of the inferior facial angle and the habits of the mother, dental irregularities, or the gender of the fetus (Table 3). According to Rotten, the value of the IFA increases with age because the chin grows anteriorly after birth. ${ }^{1}$

Paladini et al.examined 262 normal fetuses in order to establish a jaw index: Jaw Index $=(\mathrm{AP}$ mandibular diameter $/ \mathrm{BPD}) *$ $100 .{ }^{12}$ Our measurements of the jaw index in this research were between 25.3 and 34.0, with an average of 26.0. We compared the value of the jaw index and the gender and found no differences (Table 4.). This is because, as Enlow indicated, differences become visible in the prepubescent age. ${ }^{10}$ We did, however, find a correlation between the use of progesterone in the mothers and the fetal jaw index. In fetuses where the pregnant woman consumed progesterone, the value of the jaw index was smaller. A correlation was also discovered between the use of tobacco and the value of the jaw index. Fetuses whose mother did not consume tobacco had a smaller lower facial angle than in cases where the mother did consume tobacco. ${ }^{13}$

A standard parameter that is frequently measured throughout pregnancy is fetal body mass. The body mass of fetuses in our research ranged from $1203 \mathrm{gr}$ to $3701 \mathrm{gr}$ (Table 5). When the body mass was compared to the habits of pregnant women and the fetal gender we found no correlation. However, a study from 2004 has shown that consuming tobacco during pregnancy is a health concern for both the mother and the fetus. The fetuses whose mothers consumed tobacco had a lower birth weight approximately by $200 \mathrm{gr} .{ }^{14}$

New studies show that not only does the mothers' consumption of tobacco affect the fetus, but also the father's smoking habits may have the same effect on the fetus in the same way. ${ }^{13}$ The 
question, however, is, what constitutes an active smoker. Some studies show that up to five cigarettes a day do not affect fetal growth and development. ${ }^{13}$

In this research, we analyzed each profile pictures for parameters that indicate their overall development, development of the mandible, and the mandible position in the sagittal plane and an also for scoring the fetal profile. A reliable method of analyzing fetal profiles is the use of photographs. During ultrasound examinations, a profile picture of the fetuses was captured. The tip of the upper lip, lower lip, subnasale and skin pogonion was compared to three vertical lines: Dreyfus, Simon and E-line. The tip of the upper lip in fetuses was shown to be anterior in relation to all three lines, while the tip of the lower lip was anterior only to the Dreyfus and Simon lines. Both the subnasale and the skin pogonion were anterior to the Simon line, but differed in relation to the Dreyfus line: $S n$ was anterior and the Pg' was posterior. The value of the facial angle immediately prior to birth is $155.2^{\circ}$. Schwartz uses a referent value of $168^{0}+/-4^{0}$ but in adults. The value of this angle depends on the Pg' position, which is why it is smaller in fetuses and babies:
The position of the Pg' changes with the growth of the chin, i.e., after birth. The results conclude that the fetal profile is distal. Trenouth showed that the speed of mandibular growth was different throughout fetal life and did not reach the speed of the development of the maxilla, which results in embryonal retrogenia. ${ }^{15}$ Bareggi identified mandibular progenia in younger fetuses and retrogenia in older fetuses. ${ }^{16}$

\section{CONCLUSION}

In the third trimester of intrauterine life, the average value of the mandible length is $2.3 \mathrm{~cm}$. There is no difference in mandibular length between genders. The physiological position of the mandible is retrognathic and the value of the inferior facial angle was $53.3^{\circ}$. Average value of jaw index is 26 , and there are no statistical differences between genders.

\section{CONFLICT OF INTEREST}

The authors declare no conflict of interest.

\section{REFERENCES}

1. Rotten D, Levaillant JM, Martinez H, Ducou le Pointe H, Vicaut E. "The fetal mandible: a 2D and 3D sonographic approach to the diagnosis of retrognathia and micrognathia". Ultrasound Obstet Gynecol. 2002 Feb; $19(2): 122-30$.

2. Morovic CG, Monasterio L. Distraction osteogenesis for obstructive apneas in patients with congenital malformation. Plast Reconstr Surg. 2000;105:2324-2330.

3. Maldonado E, López Y, Herrera M, Martínez-Sanz E, Martínez-Álvarez C, Pérez-Miguelsanz J.Craniofacial structure alterations of foetuses from folic acid deficient pregnant mice. Ann Anat. 2018.218:59-68.

4. Loughna P, Chitty L, Evans T, Chudleigh T. Size and dating: charts recommended for clinical obstetric Practice. Ultrasound 2009;17(3):161-167.

5. Otto C, Platt L. D. "The fetal mandible measurement: an objective determination of fetal jaw size". Ultrasound in Obstetrics and Gynecology 1991;1(1):12-17.

6. Roelfsema N. M, Hop W. C, Wladimiroff J. W. Three-dimensional sonographic determination of normal fetal mandibular and maxillary size during the second half of pregnancy. Ultrasound Obstet Gynecol. 2006 Dec; 28(7):950-7.

7. Watson J, Katz V. L. Sonographic measurements of the fetal mandible: standards for normal pregnancy. Am. J Perinatol 1993;10:226-8.

8. Zalel Y., Gindes L., Achiron R. The fetal mandible: an in utero sonographic evaluation between 11 and 31 weeks' gestation. Prenatal Diagnosis. 2006; 26(2):163-167.
9. Malas M. A, Üngör B, Tağıl S. M, Sulak O. Determination of dimensions and angles of mandible in the fetal period. Surgical and Radiologic Anatomy. 2006;28(4):364-371

10. Enlow DH, Hans M. G. Essentials of facial growth. W. B. Saunders Company: Philadelphia, 1996. p.57-78.

11. Loth SR, Henneberg M. Sexually dimorphic mandibular morphology in the first few years of life. Am J Phys Anthropol 2001 Jun;115(2):179-186.

12. Paladini D, Morra T, Teodoro A, Lamberti A, Tremolaterra F, Martinelli P. Objective Diagnosis of Micrognathia in the Fetus: The Jaw Index. Obstetrics \& Gynecology 1999;93:382-386.

13. Hoyt AT, Canfield MA, Romitti PA, Botto LD, Anderka MT, Krikov SV, Feldkamp ML. Does Maternal Exposure to Secondhand Tobacco Smoke During Pregnancy Increase the Risk for Preterm or Small-for-Gestational Age Birth? Maternal and Child Health Journal 2018.

14. Gupta PC, Sreevidya S. Smokeless tobacco use, birth weight, and gestational age: population based, prospective cohort study of 1217 women in Mumbai, India. BMJ. 2004;328(7455):1538. Erratum in: BMJ 2010;340:c2191.

15. Trenouth MJ. Changes in the jaw relationships during human foetal cranio-facial growth. Br J Orthod 1985;12:33-39

16. Bareggi R, Sandrucci MA, Baldini G, Grill V, Zweyer M, Narducci P. Mandibular growth rates in human fetal development. Archives of Oral Biology 1995 February; 40(2):119-125. 